\title{
Population-specific DNA fingerprints in a neotropical pseudoscorpion (Cordylochernes scorpioides)
}

\author{
DAVID W. ZEH,${ }^{*} \dagger$ JEANNE A. ZEH, ${ }^{*} \dagger$ MARY ALICE COFFROTH $\ddagger \&$ \\ ELDREDGE BERMINGHAM* \\ *Smithsonian Tropical Research Institute, †Department of Genetics, Queens Medical Centre, University of Nottingham, \\ Nottingham, U.K. and $\ddagger$ Department of Biological Sciences, State University of New York, New York, U.S.A
}

\begin{abstract}
The pseudoscorpion, Cordylochernes scorpioides, is currently described as a single species, ranging throughout the rain forests of Central and South America. Populations from Panama and French Guiana appear morphologically and behaviourally indistinguishable. However, DNA fingerprinting, using the probe M13, revealed distinct, population-diagnostic clusters of low molecular weight bands $(<4 \mathrm{~kb})$. This appears to be the most extreme case of population differentiation in minisatellite DNA so far detected in outbred, sexually-reproducing populations. As the two populations also exhibit allozyme divergence and are reproductively incompatible at the postzygotic stage, we conclude that they are, in fact, cryptic species, the characteristics of which are apparent only at the molecular level.
\end{abstract}

Keywords: Cordylochernes scorpioides, DNA fingerprinting, minisatellite DNA, population differentiation.

\section{Introduction}

Rapid evolution in hypervariable or 'minisatellite' DNA results in restriction fragment profiles which are often unique to the individual (Jeffreys, 1985a,b). These multilocus 'DNA fingerprints' provide a powerful method for determining parentage and identifying close relatives. As knowledge of genetic relatedness is critical to many aspects of behavioural ecology, DNA fingerprinting has been increasingly applied to the investigation of social interactions ranging from extrapair paternity (Westneat, 1990) to eusociality (Reeve et al., 1990). Clearly, by providing a direct measure of fertilization success, the technique also promises to revolutionize the study of sexual selection (Burke, 1989).

By contrast, because minisatellite DNA evolves so rapidly, multilocus DNA fingerprinting is thought to have little applicability to research at the population level or above (Lynch, 1988; Burke et al., 1991). Exceptions occur when the rate of hypervariable region evolution is constrained by some mechanism

Correspondence: D. Zeh, Department of Genetics, Queens Medical Centre, University of Nottingham, Nottingham NG7 2UH, U.K. such as asexual reproduction (e.g. Nybom \& Schaal, 1990; Turner et al., 1990; Carvalho et al., 1991.), founder effects and/or inbreeding (Gilbert et al., 1990). For example, in their study of the California Channel Island fox, Gilbert et al. (1990) stress that DNA fingerprinting was effective in detecting population differentiation only because of the existence of small, isolated populations in which the fixation of restriction fragment polymorphisms can outpace the generation of fragment-length variability through recombination.'

In this paper, we document the existence of distinct multilocus DNA fingerprint patterns in two populations of a neotropical pseudoscorpion (Cordylochernes scorpioides). The significance of this research lies in the fact that population-diagnostic fragments were detected in sexually-reproducing individuals taken from large, outbred, mainland populations of what is reported to be a single species, ranging throughout the rain forests of Central and South America (Beier, 1948). Our results strongly support the recent suggestion that multilocus DNA fingerprinting may be a useful tool in the analysis of population-level differentiation (van Pijlen et al., 1991). It may also prove useful in the identification of cryptic species. 


\section{Methods}

\section{Background}

The population differentiation in minisatellite DNA reported here was discovered accidentally when individuals for a DNA fingerprinting study of sexual selection in $C$. scorpioides were obtained from two geographically distant populations (Panama and French Guiana; see Zeh \& Zeh, 1992b). Preliminary investigation of inheritance patterns suggest that minisatellites in $C$. scorpioides are, in general, inherited in a simple Mendelian fashion (D. W. Zeh \& J. A. Zeh unpublished data). In an analysis of three known families (mother, father, and four, six or eight offspring), pairwise comparisons of segregation of all paternal and maternal fragments detected only two significant cases of linkage, both of which occurred in the largest family (for discussion of minisatellite linkage analysis, see Meng et al., 1990).

\section{Study populations}

In Panama, pseudoscorpions were collected in lowland tropical forest in the former Canal Zone (Parque Nacional Soberania, Barro Colorado Island, and Gigante Peninsula). In French Guiana, collections were made along the Piste du Kaw, $50 \mathrm{~km}$ south-east of Cayenne (Zeh \& Zeh, 1992b). Individuals used for both populations were either field-collected adults or the laboratory-reared offspring of females inseminated in the field. No more than one individual per family was included in the analysis. Depending on the restriction enzyme used (HaeIII or HinfI), from 20 to 24 individuals from each population were included in the analyses.

\section{DNA preparation}

Whole adults $\left(\approx 6 \mathrm{mg}\right.$ ) were stored at $-70^{\circ} \mathrm{C}$ for later grinding in $400 \mu \mathrm{l}$ of $2 \times \mathrm{CTAB}$ extraction buffer (Doyle \& Doyle, 1987). After the addition of $1.5 \mu \mathrm{l}$ of $20 \mu \mathrm{g} \mu \mathrm{l}^{-1}$ Proteinase $\mathrm{K}$, samples were placed in a $65^{\circ} \mathrm{C}$ waterbath for $>1 \mathrm{~h}$. The DNA was then purified by performing the following extractions in succession, using a $400 \mu \mathrm{l}$ volume: one chloroform/isoamyl alcohol (24:1); two phenol/chloroform/isoamyl alcohols $(25: 24: 1)$, and one chloroform/isoamyl alcohol. Suspended DNA was then precipitated with $600 \mu \mathrm{l}$ of 95 per cent ethanol at $-20^{\circ} \mathrm{C}$ and pelleted for $30 \mathrm{~min}$ at $12,000 \mathrm{~g}$. Pellets were washed twice in cold 70 per cent ethanol, vacuum dried and resuspended in $20 \mu \mathrm{l}$ of TE buffer (10 mm Tris, 1 mм EDTA, pH 7.8, autoclaved).
DNA aliquots were digested for $6-8 \mathrm{~h}$ at $37^{\circ} \mathrm{C}$ with either 15 units of HaelII or 20 units of HinfI. Electrophoresis was then carried out in 1.0 per cent agarose gels run at 34-36 $\mathrm{V}$ for $34 \mathrm{~h}$ in circulating $1 \times \mathrm{TBE}$ buffer (Ausubel et al., 1989). To check for the consistency of digestion and to control for gel distortion (which proved to be minimal), for each gel, two samples from at least one individual were independently digested and run several lanes apart. After electrophoresis, ethidium bromide stained gels were examined under ultraviolet light to evaluate digestion quality. DNA fragments were then denatured in $1.5 \mathrm{M}$ $\mathrm{NaCl}, 0.5 \mathrm{M} \mathrm{NaOH}$ and neutralized in $1 \mathrm{~m}$ Tris, $1.5 \mathrm{M}$ $\mathrm{NaCl}$ before capillary transfer to nylon membranes (Zetabind, Cuno Inc.). Membranes were dried for $3 \mathrm{~h}$ at $80^{\circ} \mathrm{C}$.

\section{Hybridization}

The wild-type M13 bacteriophage was used as a probe in a slightly-modified 'sandwich' hybridization procedure developed by Weihe et al. (1990). Briefly, membranes were first prehybridized for 4-6 h (Westneat $e t$ al., 1988), then hybridized overnight at $65^{\circ} \mathrm{C}$ with unlabelled, single-stranded M13, washed for $20 \mathrm{~min}$ in $2 \times$ SSC, 0.1 per cent SDS, and finally hybridized for 12-16 $\mathrm{h}$ with replicative form M13 which had been labelled with ${ }^{32} \mathrm{P}$, using a random priming kit (Bethesda Research Laboratories). Membranes were washed for $20 \mathrm{~min}$ in $2 \times \mathrm{SSC}, 0.1$ per cent SDS at room temperature and again at $65^{\circ} \mathrm{C}$, and were then exposed to $\mathrm{X}$-ray film (Kodak X-omat $\mathrm{AR}$ ) at $-70^{\circ} \mathrm{C}$ for $1-7$ days with an intensifying screen.

\section{Experimental design and analyses}

In 40 of the 45 specimens, DNA extracted from the individuals $(2-4 \mu \mathrm{g})$ was divided into two equal aliquots, one for digestion with HaelII, the other with Hinfl. Four gels were run for HaellI and five for Hinfl. Each gel contained approximately equal numbers of individuals from the two populations. Interpopulation comparisons were carried out separately by enzyme.

Two methods were used to compare the within- and between-population variation in DNA fingerprint profiles. First, we used the conventional technique of calculating band-sharing coefficients, in this case to estimate levels of both intra- and interpopulation band sharing. This approach relies on the assumption that fragments of equal mobility are identical. Although valid for intrapopulation applications such as paternity assignment, this assumption may not hold when making comparisons between populations. Therefore, we also used a second, simpler method which did not 
require the assessment of band equivalence but relied only on calculating the mean fragment length for each individual.

For both the band-sharing and the fragment length analyses, we carried out intra- and inter-population comparisons in terms of (i) strongly and (ii) weakly hybridizing bands. Strongly hybridizing bands result from high sequence homology between genomic and probe DNA (Wong et al., 1987) and are therefore likely to be the most directly comparable between populations. In both populations, strongly hybridizing bands, i.e. bands still visible after higher stringency washes, were confined to the 1-4 kb region of gels. Consequently, analyses were carried out separately by two gel regions: (i) 1-4 kb inclusive, and (ii) 4-20 kb.

\section{Comparison of band-sharing coefficients}

Intrapopulation band-sharing coefficients (see Gill et al., 1985) were obtained by calculating the ratio of shared bands to the mean total number of bands in pair of individuals in adjacent (or nearly adjacent) lanes on a gel. That is, for each population, individual $\mathrm{A}$ was compared to individual $\mathrm{B}, \mathrm{B}$ to $\mathrm{C}$, etc. A similar approach was used to assess band sharing between the populations. For each gel, we compared individual A from Panama to individual A from French Guiana, etc. Bands were scored as equivalent if their centres were less than $0.5 \mathrm{~mm}$ apart.

\section{Comparison of fragment lengths}

Band positions on the autoradiographs were recorded on computer file, using a sonic digitizing tablet (IBI gel reader). Fragment sizes were then estimated with the
MacVector, version 3.5 fragment size program (IBI/ Kodak Co.). Using the positions of HindIII lambda fragments as calibration points, this program employs a least squares algorithm to estimate fragment lengths. We then used these data to compute the mean fragment length possessed by each individual (individual mean fragment length or IMFL).

Because of the large number of bands hybridized by multilocus probes and the difficulty in precisely controlling stringency conditions, between-gel comparisons are generally considered unreliable for such purposes as paternity testing (Gill, 1990). Here, however, characterization of the populations relied on a statistical description of fragment lengths rather than on band-sharing proportions. It was therefore possible to test for between-gel effects. A two-way analysis of variance (ANOVA) was performed on IMFL, with population and gel as factors. Because the number of individuals varied somewhat between gels, SAS type III sum of squares was used to calculate significance levels (SAS Institute, 1988).

\section{Results}

\section{Comparison of band-sharing coefficients}

For fragments between 1 and $4 \mathrm{~kb}$, i.e. the strongly hybridizing fragments, the between-population bandsharing coefficient for each enzyme was markedly lower than the coefficient within either the Panama of the French Guiana population (Table 1). Intrapopulation coefficients ranged between 0.286 and 0.371 , compared to interpopulation values of 0.015 and 0.079. A one-way non-parametric ANova (Krushal-

Table 1 Within- and between-population band-sharing coefficients in Cordylochernes scorpioides by restriction enzyme and gel region

\begin{tabular}{|c|c|c|c|c|c|c|}
\hline \multirow[b]{2}{*}{ Comparison } & \multicolumn{3}{|c|}{ 1-4 kb region } & \multicolumn{3}{|c|}{$4-20 \mathrm{~kb}$ region } \\
\hline & $n$ & Mean & S.E. & $n$ & Mean & S.E. \\
\hline \multicolumn{7}{|l|}{ HaeIII } \\
\hline French Guiana (FG) & 17 & 0.286 & 0.038 & 16 & 0.056 & 0.031 \\
\hline Panama (PAN) & 18 & 0.331 & 0.047 & 17 & 0.106 & 0.041 \\
\hline $\mathrm{FG} \times \mathrm{PAN}$ & 17 & 0.039 & 0.015 & 17 & 0.151 & 0.044 \\
\hline \multicolumn{7}{|l|}{ Hinfl } \\
\hline French Guiana (FG) & 14 & 0.371 & 0.058 & 11 & 0.097 & 0.068 \\
\hline Panama (PAN) & 17 & 0.354 & 0.050 & 12 & 0.212 & 0.065 \\
\hline $\mathrm{FG} \times \mathrm{PAN}$ & 17 & 0.079 & 0.032 & 12 & 0.118 & 0.060 \\
\hline
\end{tabular}

$n=$ the number of comparisons. Mean $=$ the mean band-sharing coefficient.

S.E. $=$ the standard error. 


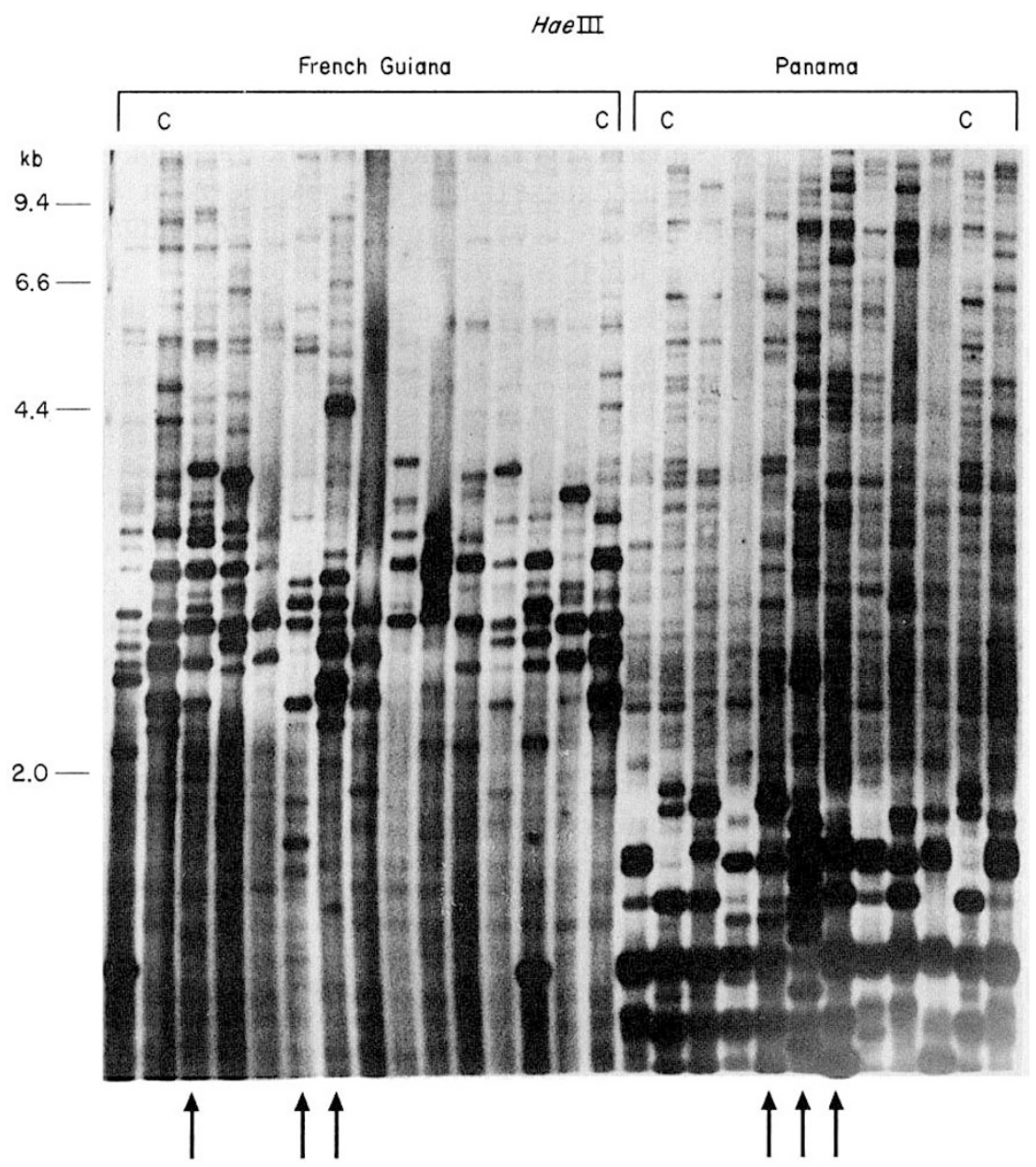

Fig. 1 Population-specific DNA fingerprints in Cordylochernes scorpioides, HaeIII-digested DNA. Individuals indicated by the arrows were unrelated and only these were included in the analysis. For each population the remaining individuals were progeny of a single female. Control lanes are indicated by ' $\mathrm{C}$ '.
Wallis test) showed these differences to be highly significant for both enzymes (HaeIII: $\chi^{2}=24.66$, d.f. $=2$, $P<0.0001 ;$ HinfI: $\chi^{2}=16.89$, d.f. $\left.=2, P=0.0002\right)$. By contrast, in the $4-20 \mathrm{~kb}$ region of the gel, i.e. for weakly hybridizing fragments, there were no significant differences in within- versus between-population bandsharing coefficients (HaeIII: $\chi^{2}=2.94, \quad$ d.f. $=2$, $P=0.230$; Hinfl: $\chi^{2}=1.98$, d.f. $=2, P=0.372$ ).

\section{Comparison of fragment lengths}

The two populations exhibited a marked difference in the frequency distribution of fragment lengths in the 1-4 kb region for both HaeIII (Fig. 3) and HinfI (Fig. 4). A comparison of population mean IMFL (Table 1) demonstrated that the minisatellites of French Guiana pseudoscorpions consisted of significantly longer fragments than those of Panama individuals in the $1-4 \mathrm{~kb}$ region of gels. By contrast, the populations did not differ significantly in the $4-20 \mathrm{~kb}$ region.

In the two-way ANOvA on fragments in the 1-4 kb range, partitioning of the variance in IMFL showed a non-significant effect of gel $\left(F_{3,35}=1.67, P=0.191\right)$ for gels carrying DNA digested with HaeIII. For this restriction enzyme, population exerted a highly significant effect $\left(F_{1.35}=109.48, P<0.0001\right)$ and accounted for approximately 56 per cent of the total variation. The interaction between gel and population was not significant $\left(F_{3,35}=0.18, P=0.9064\right)$. In the case of Hinf $\mathrm{I}$, the effect of gel, although significant $\left(F_{4,34}=2.60, P=0.0536\right)$, was weak compared to that of population $\left(F_{1,34}=185.41, P<0.0001\right)$. Population accounted for 64 per cent of the total variation in IMFL. The interaction between gel and population was significant but relatively minor $\left(F_{4,34}=4.02\right.$, $P=0.009$ ).

In the 4-20 kb range, for HaeIII, partitioning of the variance in IMFL showed a small but marginally significant effect of gel $\left(F_{3,35}=2.79, P=0.0547\right)$. Population did not exert a significant effect $\left(F_{1,35}=0.18\right.$, $P=0.6735)$ and accounted for less than 1 per cent of the total variation. The interaction between gel and population was not significant $\left(F_{3,35}=1.05\right.$, 


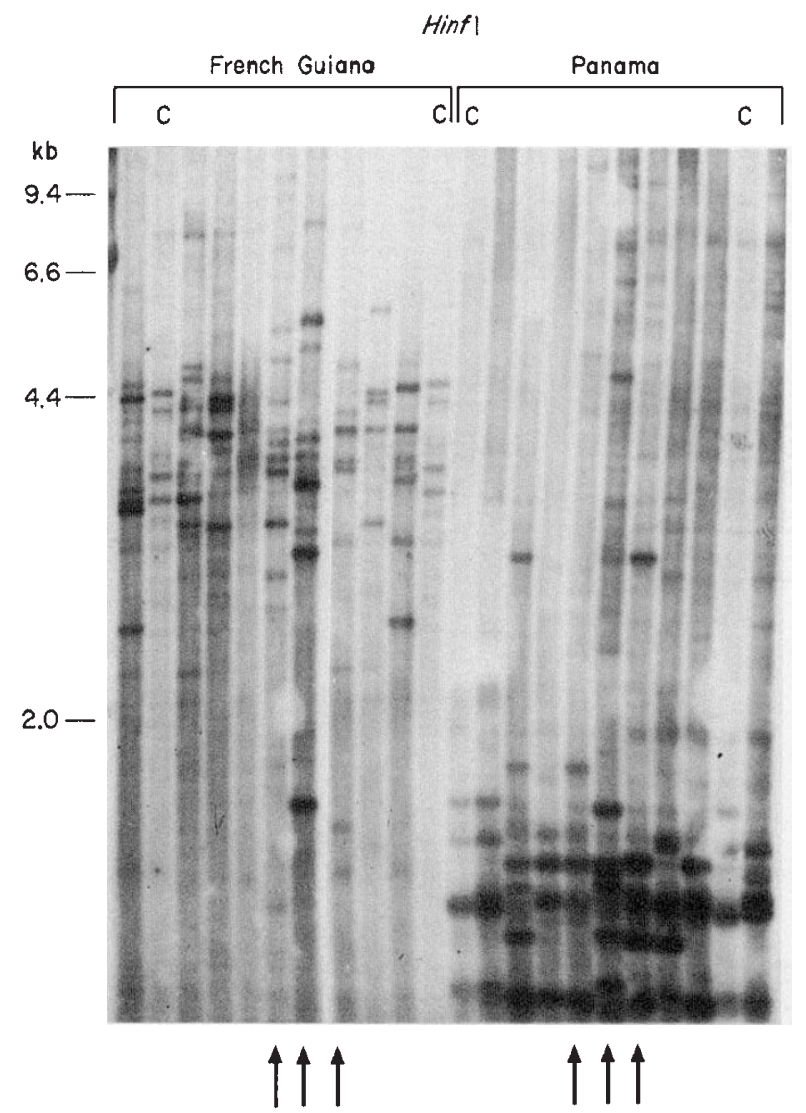

Fig. 2 Population-specific DNA fingerprints in Cordylochernes scorpioides, Hinf I-digested DNA. Other data as described in Fig. 1.
$P=0.3822)$. For $H i n f \mathrm{I}$, the effect of gel was again not significant $\left(F_{4,34}=2.10, P=0.1032\right)$. The effect of population was not significant $\left(F_{1,34}=0.54\right.$, $P=0.4666$ ) and accounted for less than 1 per cent of the total variation in IMFL. The interaction between gel and population was not significant $\left(F_{4,34}=0.89\right.$, $P=0.4787$ ).

\section{Discussion}

This study provides clear evidence that populations of C. scorpioides in Panama and French Guiana can be distinguished on the basis of their minisatellite DNA profiles. The population in Panama is characterized by the presence of short fragments $(1.2-2.2 \mathrm{~kb})$ which are virtually absent in French Guiana individuals. By contrast, pseudoscorpions from French Guiana possess a distinctive cluster of bands in the $2.5-4.0 \mathrm{~kb}$ range. The distinction between the two populations is so marked that, for HinfI, there is a 99 per cent probability of correctly assigning an individual to its source population on the basis of its mean fragment length in the $<4 \mathrm{~kb}$ range (calculated from quantile statistics, see SAS Institute, 1985: p. 350).

The population-diagnostic minisatellite bands present in $C$. scorpioides differ significantly from other population- or strain-specific DNA fingerprints so far detected [e.g. California Channel Island foxes (Gilbert et al., 1990); Minke whales (van Pijlen et al., 1991); aphids (Carvalho et al., 1991); clonal vertebrates

Table 2 Population comparisons of individual mean fragment lengths (IMFL) in Cordylochernes scorpioides by restriction enzyme and gel region

\begin{tabular}{|c|c|c|c|c|c|c|c|}
\hline \multirow[b]{2}{*}{ Population } & \multirow[b]{2}{*}{$n$} & \multicolumn{3}{|c|}{$1-4 \mathrm{~kb}$ region } & \multicolumn{3}{|c|}{$4-20 \mathrm{~kb}$ region } \\
\hline & & $\begin{array}{l}\text { Mean } \\
\text { (bp) }\end{array}$ & s.d. & S.E & $\begin{array}{l}\text { Mean } \\
\text { (bp) }\end{array}$ & s.d. & S.E. \\
\hline \multicolumn{8}{|l|}{ HaeIII } \\
\hline French Guiana & 21 & 2872 & 163 & 35 & 8842 & 1927 & 421 \\
\hline Panama & 22 & 2202 & 187 & 40 & 8227 & 1691 & 360 \\
\hline $\begin{array}{r}\text { Mean length } \\
\text { difference }\end{array}$ & \multicolumn{4}{|c|}{$670^{*}$} & \multicolumn{3}{|l|}{$615 \mathrm{~ns}$} \\
\hline Hinf $\mathrm{I}$ & & & & & & & \\
\hline French Guiana & 20 & 3094 & 264 & 59 & 8122 & 2439 & 545 \\
\hline Panama & 24 & 1961 & 315 & 64 & 8166 & 1631 & 340 \\
\hline $\begin{array}{l}\text { Mean length } \\
\text { difference }\end{array}$ & & $1133^{*}$ & & & $44 \mathrm{~ns}$ & & \\
\hline
\end{tabular}

$n=$ the number of pseudoscorpion individuals. ${ }^{*} P<0.0001$. ns: $P>0.05$. 

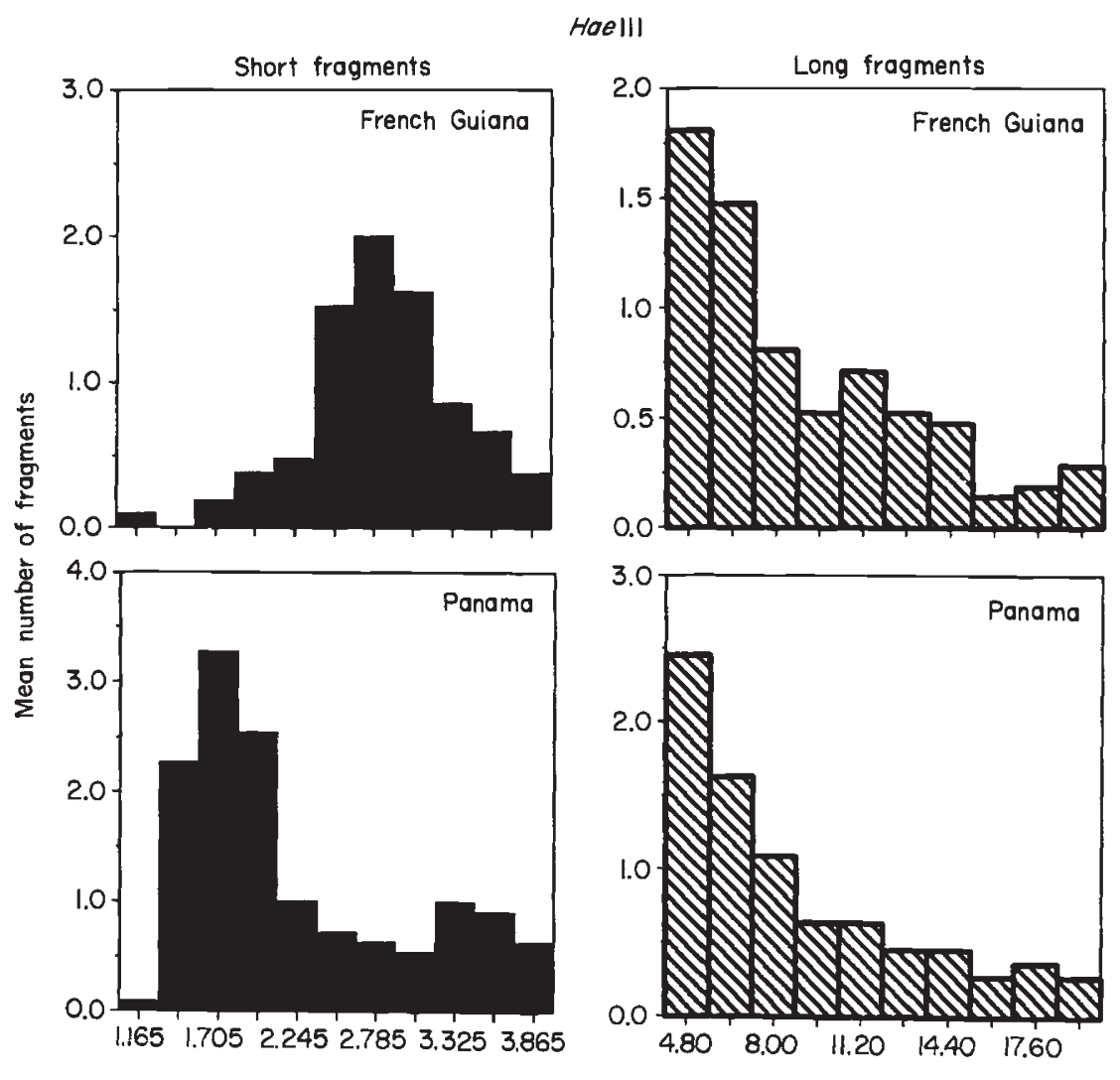

Fragment length (kb)

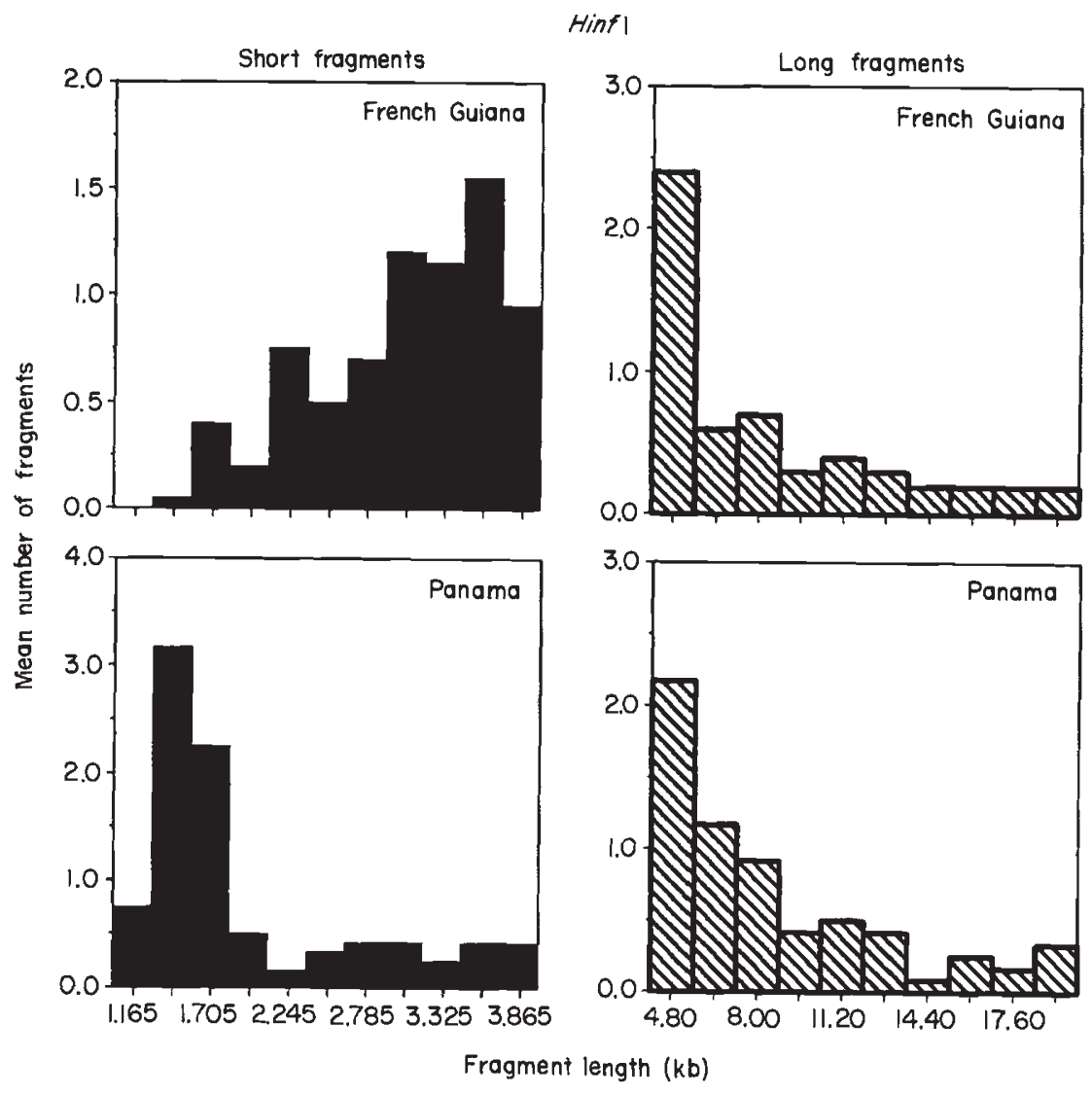

Fig. 3 Frequency distribution of HaeIIIdigested DNA fragments categorized by length and population.
Fig.4 Frequency distribution of Hinf Idigested DNA fragments categorized by length and population. 
(Turner et al., 1990) and blackberries and raspberries (Nybom \& Schaal, 1990)]. In all these cases, diagnostic minisatellite bands are associated with high levels of band sharing within populations or clones. By contrast, the intrapopulation band-sharing coefficients reported here are relatively low, indicating that individuals from both French Guiana and Panama were sampled from large, predominantly outbred populations. Consequently, neither founder effects nor inbreeding can be invoked to explain the presence of these populationdiagnostic minisatellite in $C$. scorpioides.

It may be of significance that the populationdiagnostic bands for the Panama population were short fragments in the range of $2.2 \mathrm{~kb}$ or less. In most studies, bands of this molecular weight are run off the gel because the greatest between-individual variability is thought to occur in higher molecular weight fragments (Jeffreys et al., 1985b). Consequently, as may be the case for sex-specific minisatellite bands (McRae \& Kovacs, 1991), population differences such as those found in $C$. scorpioides may well have gone undetected in the DNA fingerprints of other species.

The findings reported here are consistent with a multilocus protein electrophoresis investigation of the French Guiana and Panama populations of $C$. scorpioides. This study revealed a nearly fixed allele difference at the lactate dehydrogenase (LDH) locus, which suggests either restricted gene flow or strong population-specific selection at this locus (D. W. Zeh \& J. A. Zeh unpublished data). By contrast, in a recent multivariate morphological and behavioural study (Zeh \& Zeh, 1992a,b, and unpublished data), we found that morphological characters did not reliably distinguish between individuals from French Guiana and Panama. Both populations exhibited extreme variability in male morphological traits, with coefficients of variation of approximately 20 per cent for sexually dimorphic characters (Zeh \& Zeh, 1992a,b). Such extreme variability is apparently common to populations of $C$. scorpioides throughout Central and South America, and has proved problematic for taxonomists. Originally described as a complex of several Cordylochernes species (Beier, 1932), the complex was reclassified as a single species when re-examination of hundreds of specimens revealed extremely high levels of intraspecific' variation in external morphology (Beier, 1948).

Although the populations from French Guiana and Panama experience markedly different climates and microhabitats (Zeh et al., 1992), we have found that they share a complex set of behaviours associated with dispersal and male competition. The pseudoscorpion disperses from old to newly dead or dying trees under the elytra of the giant harlequin beetle, Acrocinus longi- manus (Zeh \& Zeh, 1992a,b, Zeh et al., 1992). In both populations, this unusual dispersal mode has been exploited by males who compete to monopolize beetle abdomens as mobile mating territories (Zeh \& Zeh, 1992a,b). In observing individuals under both field and laboratory conditions, we have failed to detect any population-specific behavioural characteristics.

To investigate the reproductive compatibility of pseudoscorpions from French Guiana and Panama, more than 50 interpopulation crosses were carried out in the laboratory (J. A. Zeh, unpublished data). Females from both populations accepted spermatophores from males of the 'foreign' population, and produced external brood sacs as a result of interpopulation mating. However, there brood sacs were always aborted, with embryonic development apparently not proceeding beyond the initial cell divisions. The two populations therefore appear to be completely reproductively incompatible at the postzygotic stage.

Molecular genetic methods, such as protein electrophoresis and mtDNA restriction fragment length analysis, have been firmly established as powerful techniques for identifying cryptic species (see reviews in Dowling et al., 1990; Murphy et al., 1990). The results of this study indicate that the morphologically and/or behaviourally cryptic species may also be detectable in the DNA fingerprint profiles of populations. The population-diagnostic minisatellite bands reported here imply minimal gene flow between Panama and French Guiana. Taken in conjunction with data on allozymes, behaviour, morphology and interpopulation reproductive compatibility, the results of our DNA fingerprinting study strongly suggest that $C$. scorpioides is, in fact, a complex of cryptic species, the characteristics of which are apparent only at the molecular level.

\section{Acknowledgements}

We would like to thank S. McCafferty for technical assistance and D. T. Parkin, I. A. van Pijlen and J. H. Wetton for useful comments. We especially thank D. T. Parkin for providing the linkage analysis program. Voucher specimens have been deposited with W. B. Muchmore (University of Rochester) and V. Mahnert (Museum d'Histoire naturelle, Switzerland) who identified the pseudoscorpions. The investigation was supported by funds from the Smithsonian Institution's Molecular Systematics and Scholarly Studies Programs and through a National Science Foundation/NATO Postdoctoral Fellowship to DWZ. 


\section{References}

AUSUBEL, F. M., BRENT, R., KINGSTON, R. E., MOORE, D. D., SEIDMAN, J. G., SMITH, J. A. AND STRUHL, K. (eds) 1989. Short Protocols in Molecular Biology. John Wiley, New York.

BEIER, M. 1932. Pseudoscorpionidea II. Subord. C. Cheliferinea. Tierreich, 58, 1-294.

BEIER, M. 1948. Phoresie und Phagophilie bei Pseudoscorpionen. Oesterreich. Zool. Z., 1, 441-497.

BURKE, T. 1989. DNA fingerprinting and other methods for the study of mating success. Trends Ecol. Evol., 4, 139-144.

BURKE, T., HANOTTE, O., BRUFORD, M. W. AND CAIRNS, E. 1991. Multilocus and single locus minisatellite analysis in population biological studies. In: Burke, T. Dolf, G., Jeffreys, A. J. and Wolff, R. (eds) DNA Fingerprinting Approaches and Applications, Birkhauser-Verlag, Basel, pp. 154-168.

CARVAlHo, G. R., MACLEAN, N., WRATTEN, S. D., CARTER, R. E. AND THURSTON, J. P. 1991. Differentiation of aphid clones using DNA fingerprints from individual aphids. Proc. $R$. Soc. Lond. B, 243, 109-114.

DOWLING, T. E., MORITZ, C. AND PALMER, J. D. 1990. Nucleic acids II: restriction site analysis. In: Hillis, D. M. and Moritz, C. (eds) Molecular Systematics, Sinauer, Sunderland, MA, pp. 250-317.

DOYLE, J. J. AND DOYLE, J. L. 1987. A rapid DNA isolation procedure for small quantities of fresh leaf tissue. Phytochem. Bull., 19, 11-15.

GILBERT, D. A., LEHMAN, N., O'BRIEN, S. J. AND WAYNE, R. K. 1990. Genetic fingerprinting reflects population differentiation in the California Channel Island fox. Nature, 344, 764767.

GILL, P. 1990. Band sharing and related matters. Fingerprint News, 2(3), 12-17.

GILL, P. JEFFREYS, A. J. AND WERRETT, D. J. 1985. Forensic applications of DNA 'fingerprints'. Nature, 318, 577-579.

JEFFREYS, A. J., WILSON, V. AND THEIN, S. L. 1985a. Hypervariable 'minisatellite' regions in human DNA. Nature, 314, 6779.

JEFFREYS, A. J., WILSON, v. AND THEIN, S. L. 1985b. Individualspecific 'fingerprints' of human DNA. Nature, 316, 76-79. printing. Mol. Biol. Evol., 5, 584-599.

MCRAE, S. B. AND KOVACS, K. M. 1991. Male-specific markers in hooded seal DNA fingerprints. Fingerprint News, 3(2), 10-12.

MENG, A., CARTER, R. E. AND PARKIN, D. T. 1990. The variability of DNA fingerprints in three species of swan. Heredity, 64, 73-80.
MURPHY, R. W., SITES, J. W. JR., BUTH, D. G. AND HAUFLER, C. H. 1990. Proteins I: Isozyme electrophoresis. In: Hillis, D. M. and Moritz, C. (eds) Molecular Systematics, Sinauer, Sunderland, MA, pp. 45-126.

NYBOM, H. AND SCHAAL, B. A. 1990. DNA 'fingerprints' reveal genotypic distributions in natural populations of blackberries and raspberries (Rubus, Rosaceae). Am. J. Bot. 77, 883-888

VAN PIJLEN, I. A., AMOS, B. AND DOVER, G. A. 1991. Multilocus DNA fingerprinting applied to population studies of the minke whale Balaenoptera acutorostrata. Rep. Int. Whal. Commn., Special Issue, 13, 245-254.

REEVE, H. K., WESTNEAT, D. F., NOON, W. A., SHERMAN, P. W. AND AQUADRO, C. F. 1990. DNA 'fingerprinting' reveals high levels of inbreeding in colonies of the eusocial naked mole rat. Proc. Natl. Acad. Sci., U.S.A ., 87, 2496-2500.

SAS InSTITUTE INC. 1985. SAS Procedures Guide for Personal Computers, Version 6 Edition. Cary, NC.

SAS INSTITUTE INC. 1988. SAS/STAT User's Guide, Release 6.03 Edition. Cary, NC.

TURNER, B. J., ELDER, J. F., LAUGHLIN, T. F. AND DAVIS, W. P. 1990. Genetic variation in clonal vertebrates detected by simplesequence DNA fingerprinting. Proc. Natl. Acad. Sci. U.S.A., 87, 5653-5657.

WEIHE, A., NIEMANN, C., LIECKFELD, D., MEIER, W. AND BÖRNER, T 1990. An improved hybridization procedure for DNA fingerprinting with the bacteriophage M13 as a probe. Fingerprint News, 2(4), 9-10.

WESTNEAT, D. F. 1990. Genetic parentage in the indigo bunting: a study using DNA fingerprinting. Behav. Ecol. Sociobiol., 27, 67-76.

WESTNEAT, D. F., NOON, W. A., HUDSON, K. R. AND AQUADRO, C. F. 1988. Improved hybridization conditions for DNA 'fingerprints' probed with M13. Nuc. Acids Res., 16, 4161. WONG, Z., WILSON, V., PATEL, I., POVEY, S. AND JEFFREYS, A. J. 1987. Characterization of a panel of highly variable minisatellites cloned from human DNA. Ann. Hum. Genet. 51, 269-288.

ZEH, D. W. AND ZEH, J. A. 1992a. Dispersal-generated sexual selection in a beetle-riding pseudoscorpion. Behav. Ecol. Sociobiol., 30, 135-142.

ZEH, D. W. AND ZEH, J. A. 1992b. On the function of harlequin beetle-riding in the pseudoscorpion Cordylochernes scorpioides (Pseudoscorpionida: Chernetidae). J. Arachnol. 20, (in press).

ZEH, D. W., ZEH, J. A. AND TAVAKILIAN, G. 1992. Sexual selection and sexual dimorphism in the harlequin beetle Acrocinus longimanus. Biotropica, 24, 86-96. 